\title{
Molecular cloning of a Coxiella burnetii gene encoding a macrophage infectivity potentiator (Mip) analogue
}

\author{
Yin-Yuan Mo, ${ }^{1}+$ Nicholas P. Cianciotto ${ }^{2}$ and Louis P. Mallavia ${ }^{1}$ \\ Author for correspondence: L. P. Mallavia. Tel: +1 509335 3323. Fax: +1 5093353517. \\ e-mail: mallavia@wsu.edu
}

\author{
1 Department of \\ Microbiology, Washington \\ State University, Pullman, \\ Washington 99164-4233, \\ USA \\ 2 Department of \\ Microbiology and \\ Immunology, \\ Northwestern University, \\ Chicago, Illinois 60611 \\ USA
}

\begin{abstract}
The gene encoding a protein that reacted with antibodies specific for Legionella pneumophila macrophage infectivity potentiator (LpMip) was cloned from Coxiella burnetii, the obligate intracellular rickettsia that causes $Q$ fever in humans. Nucleotide sequencing analysis revealed an ORF encoding a gene product of 230 amino acids with a molecular mass of $25.5 \mathrm{kDa}$ and a predicted pl of 10.7. The predicted amino acid sequence from the ORF shows similarity with Mip/Mip-like proteins of Legionella (46\%) and Chlamydia $(30 \%)$. Moreover, like LpMip, the amino acid sequence of the $\mathrm{C}$ terminus of this protein has over $35 \%$ identity to prokaryotic and eukaryotic FK506-binding proteins (FKBPs) that belong to a superfamily of immunophilins and are peptidyl-prolyl cis-trans isomerases (PPlases). When overproduced in Escherichia coli, the $C$. burnetii protein also exhibited PPlase activity. Taken together, these results demonstrate that $C$. burnetii encodes a Mip analogue (CbMip). A putative leader peptide at the $\mathbf{N}$ terminus of CbMip was detected by computer analysis. Furthermore, TnphoA mutagenesis demonstrated that in E. coli CbMip was secreted. In view of the role of Mip/Mip-like proteins in the pathogenesis of Legionella and Chlamydia, CbMip may be a C. burnetii virulence factor.
\end{abstract}

Keywords: Coxiella burnetii, Mip, virulence factor

\section{INTRODUCTION}

Coxiella burnetii is an obligate intracellular bacterium that causes Q fever in humans (Baca \& Paretsky, 1983). During the infectious process, $C$. burnetii is taken up by host cells into phagosomes which then fuse with primary lysosomes to form phagolysosomes. After several cycles of replication, the vacuoles become loaded with bacteria which are released into the extracellular environment upon bursting of the host cell. Formation of the phagolysosome is a critical step during infection because the acidic environment of the phagolysosome appears to activate the metabolism of $C$. burnetii (Hackstadt \& Williams, 1981). Therefore, microbial biochemical factors

† Present Address: Department of Tumor Cell Biology, St Jude Children's Research Hospital, 322 North Lauderdale, Memphis, TN 38101, USA.

Abbreviations: FKBP, FK506-binding protein; Mip (mip), macrophage infectivity potentiator (gene); PPlase, peptidyl-prolyl cis-trans isomerase.

The GenBank accession number for the nucleotide sequence data reported in this paper is U14170. that support initiation of infection or phagolysosomal survival can be considered to be important virulence factors. While several factors have been proposed to contribute to the virulence of C. burnetii (Baca et al., 1993; Heinzen et al., 1992; Hendrix et al., 1993), little is known about its mechanisms of uptake and survival in phagolysosomes.

As a group, intracellular bacteria have evolved strategies for invasion, intracellular survival and growth (Moulder, 1985) and consequently, they may have similar infection or survival mechanisms. Although $C$. burnetii is a phylogenetically distinct organism, a comparison of $16 \mathrm{~S}$ ribosomal RNA sequences suggests that facultatively intracellular bacteria of the genus Legionella are most closely related to $C$. burnetii (Weisburg et al., 1989). Indeed, the organisms share similar intracellular growth compartments at least at the early stages of infection. In searching for virulence factors of Legionella pneumophila, Cianciotto et al. (1989) identified a gene encoding a $24 \mathrm{kDa}$ surface protein involved in macrophage infection which they designated mip (macrophage infectivity potentiator). Since then mip-like genes have been cloned from other 
intracellular bacteria, including Chlamydia trachomatis, and the gene products shown to possess amino acid sequence similarity to Legionella pneumophila Mip (Bangsborg et al., 1991; Cianciotto et al., 1990a; Fischer et al., 1992; Lundemose et al., 1992). Genetic data indicate that Mip plays an important role as a virulence factor in $L$. pneumophila, since mutations of the mip gene cause a reduction in intracellular infection (Cianciotto et al., 1990 b, 1995 a ; Cianciotto \& Fields, 1992).

Recently Mip/Mip-like proteins have been shown to belong to the FK506-binding protein (FKBP) family within the superfamily of immunophilins (see review by Hacker \& Fischer, 1993). Although Mip/Mip-like proteins are large molecules $(\geqslant 24 \mathrm{kDa})$ compared to eukaryotic FKBPs, the proteins share significant amino acid sequence similarity and are peptidyl-prolyl cis-trans isomerases (PPlases). PPIase, in free form, catalyses the slow conformational interconversion of peptidyl-prolyl bonds in oligopeptides and proteins (Fischer \& Schmid, 1990), suggesting a function in protein folding and trafficking. To date a number of FKBPs have been characterized from different sources and all possess PPIase activity which is inhibited by the immunosuppressive drugs FK-506 and rapamycin (Etzkorn et al., 1993). While the actual function of the PPlase is not yet clear, the enzymic activity of Mip/Mip-like proteins appears to be related to the ability of the organisms to initiate infection. For instance, pretreatment of Chl. trachomatis with FK506 or rapamycin significantly reduces the infection of host cells in cell culture (Lundemose et al., 1993).

We have previously reported the possible occurrence of a Mip analogue in C. burnetii and other rickettsiae, including the genus Rochalimea, based on DNA hybridization and immunoblotting data (Cianciotto et al., 1995b). In this paper we describe the cloning, nucleotide sequence and expression of the $C$. burnetii mip gene (cbmip). The identified $C$. burnetii Mip analogue (CbMip) represents a new member of the Mip/Mip-like protein family.

\section{METHODS}

Bacterial strains, plasmids, media and growth conditions. Bacterial isolates (C. burnetii, Escherichia coli and L. pneumophila) and plasmids used in this study are listed in Table 1.

E. coli cultures were routinely maintained in Luria-Bertani (LB) medium at $37^{\circ} \mathrm{C}$; SOC medium $\left(1^{-1}: 20 \mathrm{~g}\right.$ bacto-tryptone, $5 \mathrm{~g}$ bacto-yeast extract, $0.5 \mathrm{~g} \mathrm{NaCl}, 20 \mathrm{mM}$ glucose; Ausubel et al., 1989) was used for growing E. coli strain Top10 (Invitrogen) carrying the cbmip gene on $\mathrm{p} T \mathrm{rcB}$ expression vectors (Invitrogen). L. pneumopbila was grown on buffered charcoalyeast extract agar medium (Cianciotto et al., 1989) at $37^{\circ} \mathrm{C}$. C. burnetii was grown in embryonated yolk sacs and purified as previously described (Hendrix \& Mallavia, 1984). When needed, antibiotics were incorporated into media at the following concentrations to maintain plasmids in $E$. coli: ampicillin, $100 \mu \mathrm{g} \mathrm{ml}^{-1}$; kanamycin, $50 \mu \mathrm{g} \mathrm{ml}^{-1}$ and tetracycline, $24 \mu \mathrm{g} \mathrm{ml} \mathrm{m}^{-1}$.

Screening of the $\mathbf{C}$. burnetii genomic library. Preparation of $L$. pneumophila Mip (LpMip)-specific polyclonal antibodies from rabbits has been described elsewhere (Cianciotto et al., 1990a). The LpMip-specific antibodies were used to screen a bac- teriophage $\lambda$ ZAPII (Stratagene) genomic DNA library of the $C$. burnetii Nine Mile isolate for clones expressing a Mip analogue. The C. burnetii genomic DNA library (Mo \& Mallavia, 1994) was constructed with EcoRI-digested $\lambda$ ZAPII arms. Bacteriophage $\lambda$ ZAPII was mixed with E. coli strain XL1-blue (Bullock et al., 1987) in LB containing $0.7 \%$ agar at $\sim 500$ viruses per plate and poured over a bottom layer of LB agar (1.5\%). Plates were incubated for $4 \mathrm{~h}$ at $42^{\circ} \mathrm{C}$ when plaques were just visible. Induction was done with IPTG (Gibco) by overlaying the plates with a nitrocellulose membrane (Schleicher \& Schuell) impregnated with $10 \mathrm{mM}$ IPTG and incubating for a further $10 \mathrm{~h}$ at $37^{\circ} \mathrm{C}$. The membrane was analysed as for Western blotting (Ausubel et al., 1989) using LpMip-specific antibodies (see below). Once positive plaques were identified, secondary screening was conducted to obtain pure, positive clones which were excised in vivo in the presence of helper phage R408 (Russel et al., 1986). Positive clones were verified by incubating E. coli harbouring an appropriate plasmid in LB broth supplemented with $1 \mathrm{mM}$ IPTG at $37^{\circ} \mathrm{C}$ overnight with shaking at 250 r.p.m. and analysing cell lysates by Western blotting using the LpMipspecific antibodies (see below).

Recombinant DNA techniques. A positive clone, pYMA1, isolated from the genomic library, contained a $5.3 \mathrm{~kb}$ EcoRI DNA fragment in pSK (Fig. 1). Physical mapping and subcloning showed that the putative cbmip gene was within a $1.7 \mathrm{~kb}$ EcoRI-ClaI fragment of a pSK recombinant, designated pYMA1.1 (Fig. 1). pYMA1.1 was used as a DNA template for sequencing. Digestion of pYMA1.1 with HindIII and selfligation resulted in pYMA1.4 which carried a DNA insert of 187 bp encompassing the upstream region of the cbmip gene and the coding region for the first 44 amino acids of the CbMip (Fig. 1). pYMA1.6 was constructed by ligating the cloned $1.7 \mathrm{~kb}$ EcoRI-ClaI fragment of pYMA1.1 into pUC19 such that the cbmip gene was in the opposite orientation to the lac promoter on the vector. Deletion of the $1.7 \mathrm{~kb}$ EcoRI-ClaI fragment of pYMA1 and religation resulted in pYMA1.10. To overproduce the CbMip protein, plasmids pYMA1.14-1 and pYMA1.14-2 were constructed. A 694 bp DNA fragment (nucleotides 65759, see Results, Fig. 3a) was first amplified from pYMA1 by PCR using a primer pair A1-R0 (5' GAAACGAT'TGATTTTAC) and A1-U1 (5' CTGAGGT'T'T'TAT'T'TCT'T). The product was separated on a $1.5 \%$ agarose gel, purified using GeneClean Kit II (Bio101) and cloned into pCRII (Invitrogen). $E$. coli strain $\mathrm{INV} \alpha \mathrm{F}^{\prime}$ (Invitrogen) carrying recombinant plasmids were identified as white colonies on ampicillincontaining LB agar plates supplemented with X-Gal. An insert of the recombinant plasmid was excised by digestion with EcoRI and the fragment ligated into EcoRI-digested p TrcB previously treated with shrimp alkaline phosphatase (Amersham). Insert orientation was determined by restriction mapping. The plasmid, pYMA1.14-1, had the cbmip gene fused in-frame with the sequence encoding the leader peptide of the vector derived from bacteriophage $\mathrm{T} 7$ gene 10 and gene expression was controlled by the IPTG-inducible trc promoter on pTrcB. pYMA1.14-2 contained the same DNA fragment in pTrcB, but in an opposite orientation. Using the same strategy, a $582 \mathrm{bp}$ DNA fragment amplified using primers A1-R1 (5' C'TGGAAAAGCTTTCAGA) and A1-U1 (see above) was cloned into $\mathrm{p}$ TrcC in-frame to construct pYMA1.35-1. This fragment encoded CbMip lacking the $39 \mathrm{~N}$ terminus amino acids. The junction regions of the recombinant plasmids and the cloned inserts were verified by nucleotide sequencing. The presence of six histidine residues in tandem in the bacteriophage T7 gene 10 leader sequence allows purification of unprocessed fusion proteins using a nickel-chelating resin (Invitrogen).

TnphoA mutagenesis. Plasmid pYMA1.6 was subjected to 
Table 1. Bacterial strains and plasmids

\begin{tabular}{|c|c|c|}
\hline Strain or plasmid & Relevant characteristics & Source or reference \\
\hline \multicolumn{3}{|l|}{ E. coli } \\
\hline XL1-blue & $\begin{array}{l}\text { end } A 1 \text { bsd } \mathrm{R} 17\left(\mathrm{r}_{\mathrm{k}}{ }^{-} \mathrm{m}_{\mathrm{k}}{ }^{+}\right) \sup E 44 \text { thi-1 } \operatorname{rec} A \text { gyr } A 96 \\
\operatorname{rel} A\left(l a c^{-}\right)\left[\mathrm{F}^{\prime} \text { pro } A B^{+} \text {lac }{ }^{\mathrm{q}} Z \Delta \mathrm{M} 15 \operatorname{Tn} 10\left(\mathrm{Tc}^{\mathrm{R}}\right)\right]\end{array}$ & Stratagene \\
\hline $\mathrm{INV} \alpha \mathrm{F}^{\prime}$ & 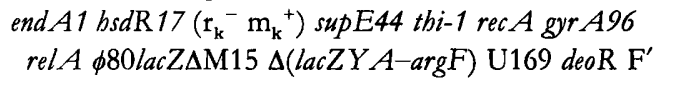 & Invitrogen \\
\hline Top10 & $\begin{array}{l}m c r A \Delta(m r r-b s d R M S-m c r B C) \phi 80 \text { lac } Z \Delta \mathrm{M} 15 \\
\Delta l a c X 74 \operatorname{deoR} \operatorname{rec} A 1 \text { araD139 } \Delta(\text { ara leu }) 7697 \text { galU } \\
\text { galK } r p s L \text { end } A 1 \text { nupG }\end{array}$ & Invitrogen \\
\hline $\mathrm{CC} 118$ & $\begin{array}{l}\text { araD139 } \Delta(\text { ara leu }) 7697 \Delta l a c X 74 \text { pho } A \Delta 20 \text { galEK thi } \\
\quad \text { rpsE rpoB argE rec } A 1\end{array}$ & $\begin{array}{l}\text { Manoil \& Beckwith } \\
\text { (1985) }\end{array}$ \\
\hline \multicolumn{3}{|l|}{ L. pneumophila } \\
\hline $130 \mathrm{~b}$ & Clinical isolate (Wadsworth strain) $m i p^{+}$ & $\begin{array}{l}\text { Cianciotto et al. } \\
\text { (1989) }\end{array}$ \\
\hline \multicolumn{3}{|l|}{ C. burnetii } \\
\hline Nine Mile & Acute disease isolate plasmid QpH1 & $\begin{array}{l}\text { Samuel et al. } \\
\text { (1985) }\end{array}$ \\
\hline $\mathrm{K}$ & Chronic disease isolate plasmid QpRS & $\begin{array}{l}\text { Samuel et al. } \\
\text { (1985) }\end{array}$ \\
\hline Priscilla & Goat abortion isolate plasmid QpRS & $\begin{array}{l}\text { Samuel et al. } \\
\text { (1985) }\end{array}$ \\
\hline$S$ & Chronic disease isolate, plasmid-less & $\begin{array}{l}\text { Samuel et al. } \\
\text { (1985) }\end{array}$ \\
\hline \multicolumn{3}{|l|}{ Plasmid } \\
\hline pUC19 & $A p^{R}$ cloning vector & BRL \\
\hline pSK & $A p^{R}$ cloning vector & Stratagene \\
\hline pCRII & $\mathrm{Ap}^{\mathrm{R}} \mathrm{Km}^{\mathrm{R}}$ PCR cloning vector & Invitrogen \\
\hline $\mathrm{p} \operatorname{TrcB} / \mathrm{p} \operatorname{Trc} \mathrm{C}$ & $A p^{R}$ expression vector & Invitrogen \\
\hline pYMA1 & $\begin{array}{l}\text { pSK carrying cbmip on a } 5.3 \mathrm{~kb} \text { EcoRI DNA } \\
\text { fragment }\end{array}$ & This study \\
\hline pYMA1.1 & $\begin{array}{l}\text { pSK carrying cbmip on a } 1.7 \mathrm{kbClaI}-E c o \mathrm{RI} \\
\text { fragment }\end{array}$ & This study \\
\hline pYMA1.4 & $\begin{array}{l}\text { pSK carrying } 187 \text { bp containing the upstream } \\
\text { region and the region encoding the first } 44 \text { amino } \\
\text { acids of the cbmip gene product }\end{array}$ & This study \\
\hline pYMA1.6 & $\begin{array}{l}\text { pUC19 carrying same cbmip as pYMA1.1 but } \\
\text { opposite in orientation to lac promoter }\end{array}$ & This study \\
\hline pYMA1.10 & $\begin{array}{l}\text { pSK carrying a } 3.6 \mathrm{~kb} \text { partially digested } C l a \mathrm{I}-E c o \mathrm{RI} \\
\text { fragment from pYMA } 1\end{array}$ & This study \\
\hline pYMA1.14-1 & $\mathrm{p}$ TrcB carrying $c b m i p$ in frame & This study \\
\hline pYMA1.14-2 & Same as pYMA1.14-1 except opposite orientation & This study \\
\hline pYMA1.35-1 & $\begin{array}{l}\text { pTrcC carrying cbmip missing the coding sequence } \\
\text { for the } 39 \text { amino acids at the } \mathrm{N} \text { terminus of the } \\
\text { gene product }\end{array}$ & This study \\
\hline pYMA1.201 & cbmip:: Tnpho $A$ in pYMA1.6 & This study \\
\hline
\end{tabular}

Tnpho $A$ mutagenesis (Manoil \& Beckwith, 1985). E. coli strain CC118 $\left(\mathrm{PhoA}^{-}\right)$was first transformed with pYMA1.6 and then transfected with $\lambda:: \operatorname{Tn} p b o A$. Potential cbmip:: $\operatorname{Tn} p h o A$ fusions were selected on ampicillin-containing LB agar plates supplemented with 5-bromo-4-chloro-3-indolyl-phosphate (X-P) and identified by physical mapping of the plasmids (pYMA1.201). When necessary, the fine structure of $\operatorname{Tn} p h o A$ inserts in the target plasmid was determined by nucleotide sequencing using the primer (5' CCGGT'T'TCCAGAACAG) complementary to the DNA sequence of the $5^{\prime}$ end of the $p b o A$ gene (Manoil \& Beckwith, 1985).

DNA sequencing, sequence analysis and protein sequencing. Nucleotide sequences were determined by the method of Sanger et al. (1977) using Sequenase version 2.0 (Amersham). In addition to M13 universal and reverse primers (Yanisch-Perron et al., 1985), the following customized sequencing primers were used: A1-R0 (see above), A1-R1 (see above), A1-R2 (5' AAGTCACCGTTAAT'TAC), A1-U1 (see above) and A1-U2 


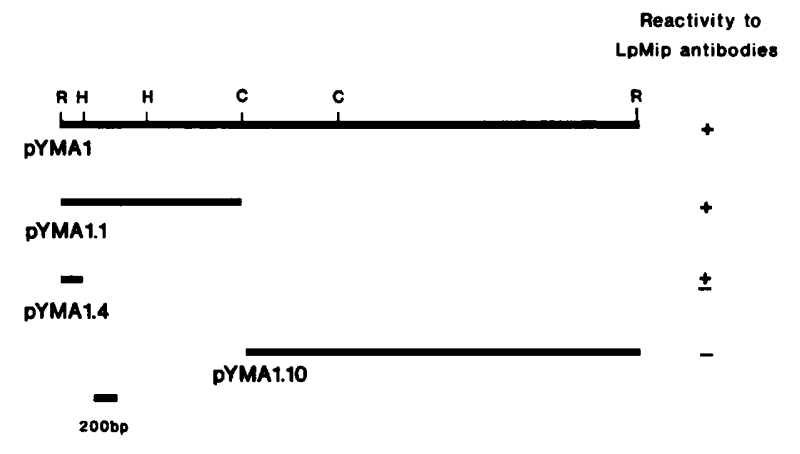

Fig. 1. Physical map of pYMA1 and its subclones, and the reactivity of cloned gene products with LpMip-specific antibodies. A $5.3 \mathrm{~kb}$ EcoRI DNA fragment in PYMA1 was originally isolated from a $C$. burnetii genomic $\lambda Z A P I I$ library. Abbreviations for restriction enzymes: C, Clal; H, Hindlll; R, EcoRI. The ability of the cloned gene products to react with LpMip-specific antibodies is indicated as + , positive, \pm , weakly positive and - , negative.

(5' GCCTGCAAGACTTTGTA) (Ransom Hill Bioscience). The DNA sequence and deduced amino acid sequence data were analysed using the GCG Sequence Analysis package (Devereux et al., 1984). Protein sequencing of the $\mathrm{N}$ terminus of CbMip was carried out by the Biochemistry Bioanalysis service at Washington State University.

PCR amplification. All PCR was carried out in a DNA ThermoCycler (Perkin-Elmer) using a GenAmp kit (PerkinElmer). The PCR reaction contained $200 \mu \mathrm{M}$ of each nucleotide dATP, dGTP, dTTP and dCTP, $1 \mu \mathrm{M}$ each of primers, $50 \mathrm{mM}$ $\mathrm{KCl}, 10 \mathrm{mM}$ Tris $/ \mathrm{HCl}\left(\mathrm{pH} \mathrm{8.3)}, 1.75 \mathrm{mM} \mathrm{MgCl}_{2}, 1 \mathrm{ng}\right.$ genomic DNA ml $l^{-1}$ or $10 \mathrm{pg}$ plasmid DNA ml$l^{-1}$ as a template and 2.5 units Taq DNA polymerase per $100 \mu \mathrm{l}$ solution. The amplification protocol consisted of 30 cycles of $0.5 \mathrm{~min}$ at $94^{\circ} \mathrm{C}, 1 \mathrm{~min}$ at $42{ }^{\circ} \mathrm{C}$ and $0.5-1 \mathrm{~min}$ at $72{ }^{\circ} \mathrm{C}$. $\mathrm{PCR}$ products were separated in a $1.5 \%$ agarose gel and purified using GeneClean Kit II.

Primers A1-R1 and A1-U1 were used for amplifying the cbmip gene from various $C$. burnetii isolates.

Immunological detection of CbMip by LpMip-specific antibodies. E. coli strain XL1-blue carrying an appropriate plasmid was incubated in LB broth with ampicillin and $1 \mathrm{mM}$ IPTG at $37^{\circ} \mathrm{C}$ overnight, pelleted and lysed in $1 \times$ Laemmli buffer (Laemmli, 1970). For isolation of L. pneumophila proteins, strain $130 \mathrm{~b}$ was grown on buffered charcoal-yeast extract agar medium (Cianciotto et al., 1989) for $3 \mathrm{~d}$ at $37^{\circ} \mathrm{C}$. The bacteria were soaked with $4 \mathrm{ml}$ PBS per plate for $2 \mathrm{~h}$ at room temperature (RT), collected, centrifuged and suspended in $1 \times$ Laemmli buffer. After separation by SDS-PAGE ( $15 \%$ separation gel), the proteins were transferred to a nitrocellulose membrane in transfer buffer (Ausubel et al., 1989) for $2 \mathrm{~h}$ at $250 \mathrm{~mA}$. Immunological reactions and washes were conducted at $26^{\circ} \mathrm{C}$ with gentle shaking. The membrane was soaked in blocking solution $[9.5 \%(\mathrm{w} / \mathrm{v})$ powdered milk in $20 \mathrm{mM}$ Tris/HCl, $\mathrm{pH} 7.4,0.87 \%$ (w/v) $\mathrm{NaCl}$ (TBS)] for $1 \mathrm{~h}$ and washed in $0.05 \%$ Tween 20 in TBS (TBST). Proteins were reacted with LpMipspecific antibodies $(1: 1000)$ in blocking solution for at least $1 \mathrm{~h}$. After three washes with TBST, horseradish-peroxidaseconjugated goat anti-rabbit antibodies (Sigma) diluted 1:1000 were added, incubated for $1 \mathrm{~h}$, washed and signals visualized by adding a 4-chloro-1-naphthol solution containing $0.03 \%(\mathrm{w} / \mathrm{v})$ hydrogen peroxide in TBS.
In vitro transcription and translation of the cbmip gene. To express the cbmip gene, plasmids were purified by $\mathrm{CsCl}$ gradient centrifugation and transcribed and translated in vitro using an E. coli extract (Promega). Proteins were labelled with $\left[{ }^{35}\right.$ S]methionine (DuPont NEN) and separated by SDS-PAGE $(15 \%)$ using a standard protocol (Ausubel et al., 1989). The gel was dried and exposed to X-ray film.

Overexpression and purification of CbMip protein. Bacterial cells (E. coli strain Top10) carrying pYMA1.14-1 were grown in $5 \mathrm{ml} \mathrm{SOC}$ containing ampicillin at $37^{\circ} \mathrm{C}$ at 300 r.p.m. to an OD of $\sim 0.6$, and induced with $1 \mathrm{mM}$ IPTG. At each time point after induction, a $0.5 \mathrm{ml}$ sample was taken, pelleted and suspended in $1 \times$ Laemmli buffer. To examine the solubility of the overproduced protein, $50 \mathrm{ml}$ of the induced cell culture was harvested and resuspended in $10 \mathrm{ml} 20 \mathrm{mM}$ sodium phosphate buffer $(\mathrm{pH} 7 \cdot 0)$ containing $500 \mathrm{mM} \mathrm{NaCl}$, and sonicated for a total of 2 min. Bacterial cell debris was separated from soluble proteins by centrifugation at $9000 \mathrm{~g}$ for $15 \mathrm{~min}$ and the pellet resuspended in $10 \mathrm{ml} 0.5 \%$ Triton X-100 containing $10 \mathrm{mM}$ EDTA to solubilize membrane proteins. The Triton-containing suspension was further centrifuged under the same conditions to separate Triton-soluble and -insoluble proteins. As a control, the plasmid carrying $c b m i p$ in the opposite orientation to the trc promoter of $\mathrm{p} \operatorname{TrcB}$ (pYMA1.14-2) was subjected to the same process. Protein samples were resolved by SDS-PAGE (15\%) and stained with Coomassie Brilliant Blue G-250 (Neuhoff et al., 1985).

Attempts to purify the recombinant protein using a nickelcontaining column (Invitrogen) were unsuccessful since the recombinant CbMip protein appeared to be processed. Consequently, gel filtration and ion exchange chromatography were employed (Reiland, 1970). Total protein extracts containing CbMip were passed through a Bio-Gel P10 column (Bio-Rad). Major fractions containing CbMip, as determined by SDSPAGE, were pooled and further purified by loading partially purified CbMip on a CM-Sephadex C25 (Sigma) column equilibrated with $10 \mathrm{mM}$ sodium phosphate buffer $(\mathrm{pH} 7 \cdot 0)$. CbMip was eluted with a linear gradient of $10 \mathrm{mM}$ sodium phosphate buffer containing $0-0.5 \mathrm{M} \mathrm{NaCl}(\mathrm{pH} 7.0)$ at $4{ }^{\circ} \mathrm{C}$ and monitored by absorbance at $280 \mathrm{~nm}$. The major peak containing CbMip eluted at $\sim 0.15 \mathrm{M} \mathrm{NaCl}$.

Enzyme assay. The assay for PPIase activity of CbMip was conducted using the method of Kofron et al. (1991). In brief, purified CbMip protein at concentrations of $0,0 \cdot 03,0.06,0 \cdot 12$, $0 \cdot 3,0 \cdot 6,0 \cdot 9$ and $1.2 \mu \mathrm{M}$ was incubated in $1 \mathrm{ml} 35 \mathrm{mM}$ HEPES buffer ( $\mathrm{pH} 7.8$ ) containing $0.25 \mathrm{mg} \mathrm{ml}^{-1} \alpha$-chymotrypsin at $0^{\circ} \mathrm{C}$; the reaction was initiated by adding $10 \mu \mathrm{l}$ succinyl-Ala-Phe-ProPhe- $p$-nitroanilide (Bachem). Activity of PPIase was calculated according to Harrison \& Stein (1990). Inhibition assays at $100 \mathrm{nM}$ CbMip were carried out under the same conditions in the presence of various concentrations of rapamycin (WyethAyerst) dissolved in absolute ethanol. The colour change resulting from hydrolysis of the substrate was monitored at $390 \mathrm{~nm}$.

\section{RESULTS}

\section{Isolation of clones containing the cbmip gene}

Approximately 2500 plaques were screened by LpMipspecific antibodies and three were positive. After in vivo excision, plasmid DNAs were analysed by physical mapping. All three clones contained the same $5.3 \mathrm{~kb}$ EcoRI DNA fragment and the plasmid was designated 


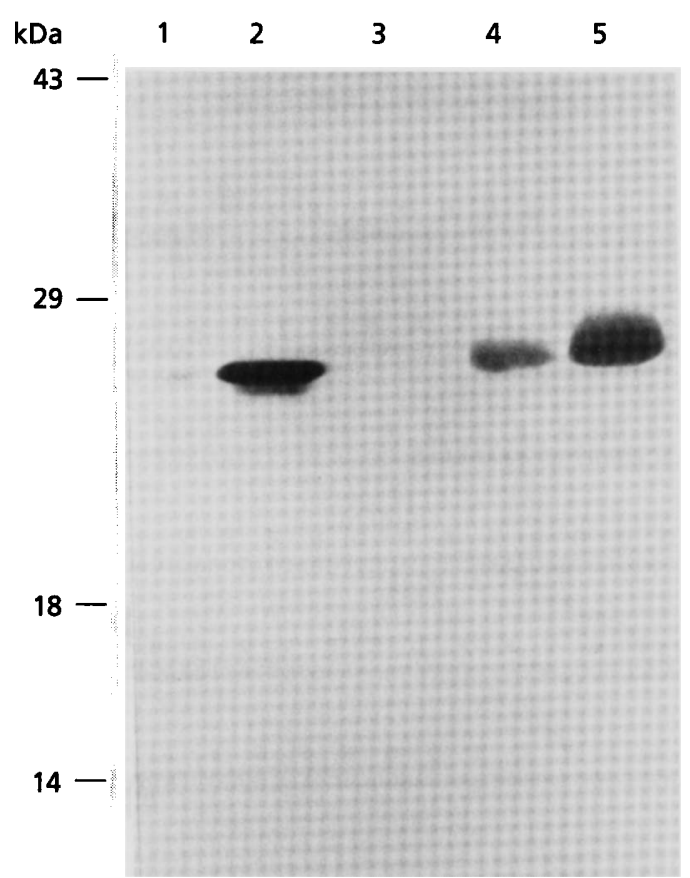

Fig. 2. Western blotting analysis of Mip/Mip-like proteins using LpMip-specific polyclonal antibodies. Lanes: proteins extracted from 1, C. burnetii Nine Mile isolate; 2 , L. pneumophila strain 130b; 3 and 4, E. coli strain XL1-blue carrying pSK and pYMA1, respectively; 5 , purified CbMip. Note that the positive protein band from the different sources is about the same molecular mass. Protein size markers are given in $\mathrm{kDa}$ on the left.

pYMA1 (Fig. 1). Southern hybridization of C. burnetii and $E$. coli genomic DNA using the $\left[\alpha^{32} \mathrm{P}\right] \mathrm{dCTP}$-labelled $5.3 \mathrm{~kb}$ EcoRI insert of PYMA1 as a probe verified that pYMA1 was cloned from the C. burnetii Nine Mile isolate. Western blotting demonstrated that pYMA1 was capable of encoding a protein that reacted with LpMip-specific antibodies (Fig. 2). Subcloning combined with Western blotting analysis localized the $c b m i p$ gene within a $1.7 \mathrm{~kb}$ EcoRI-ClaI fragment (pYMA1.1) (Fig. 1).

\section{Sequence analysis}

Nucleotide sequencing of $892 \mathrm{bp}$, starting from the EcoRI site on pYMA1.1, revealed an ORF capable of encoding a gene product comprising 230 amino acids with a molecular mass of $25 \cdot 5 \mathrm{kDa}$ (Fig. 3a). This protein was expected to be highly basic with a $\mathrm{pI}$ of $10 \cdot 7$, as predicted by computer analysis. A relatively conserved promoter region for E. coli (Hawley \& McClure, 1983) and $C$. burnetii (Mallavia, 1991) was detected upstream of the gene. In addition, at 7 bases upstream of the ATG codon was a putative ribosome-binding site (RBS), AGGAGA (Shine \& Dalgarno, 1975). At the $3^{\prime}$ end of this sequence was a potential termination signal similar to those in the C. burnetii bpt $A B$ operon, the transposase gene and citrate synthase gene (Heinzen \& Mallavia, 1987; Hoover et al., 1992; Vodkin \& Williams, 1988). Computer analysis indicated it could form a stem-loop structure with a free energy of $-41 \cdot 5$. Hydrophobicity analysis (Kyte \& Doolittle, 1982) suggested that except for the 21 amino acid leader peptide (Fig. 3 a), the protein was highly hydrophilic. Codon usage of the cbmip gene was biased compared to highly expressed $E$. coli proteins but within the range of most C. burnetii proteins (Hoover \& Vodkin, 1991).

\section{Amino acid sequence identity and similarity between CbMip and Mip/Mip-like proteins of Legionella and Chlamydia as well as FKBPs}

When the deduced amino acid sequence of the ORF was compared to that of the Mip of L. pneumophila (LpMip), an overall $46 \%$ identity was detected by the GAP program (Fig. 3b). The two proteins exhibit no gap in the alignment of their entire sequences and the molecular masses of the proteins are very close. Sequence identity of CbMip with the larger, $27 \mathrm{kDa}$, Chlamydia trachomatis Mip-like protein (CtMip) was lower (30\% identity). Furthermore, a search of protein databases using the FASTA program revealed amino acid sequence conservation of the $C$ terminus of this ORF with respect to those of prokaryotic and eukaryotic FKBPs (Mozier et al., 1990; Standaert et al., 1990; Nelson et al., 1991; Pahl \& Keller, 1992; Sampson \& Gotchlich, 1992). For instance, the 140 amino acids of CbMip at the C-terminal region shared $>35 \%$ identity to FKBP from a variety of sources (data not shown). Computer analysis using the MOTIFs program showed that, with very few exceptions, all Mip/Mip-like proteins and FKBPs had two signature patterns: (1), 12-13 amino acids at the $\mathrm{N}$ terminus of FKBP, $(\mathrm{L}, \mathrm{I}, \mathrm{V}, \mathrm{M}, \mathrm{C}) \mathrm{XYXGX}(\mathrm{L}, \mathrm{F}) \mathrm{X}[2,3] \mathrm{GXFD}$ (where amino acids in parentheses means any one of the amino acids may be present and $X[2,3]$ means that any 2 or 3 amino acids may be present); and (2), 17-18 amino acids at the $C$ terminus of FKBP, (A,G)YGX[2](S,A,G,R)X[2,3] $(G, P) X I X[5] L(L, I, V) F$. CbMip had an identical pattern at amino acids 153-166, VNYEGRLINGTVFD, and amino acids 208-226, AYGEQGAPGVIGPNEALIF (Fig. 3 b). Among the amino acids that form the signature patterns, four were shown to be involved in binding to FK506 (Hacker \& Fischer, 1993), indicative of functional conservation. In LpMip, Asp-162 was shown by site-directed mutagenesis (Ludwig et al., 1994) to be necessary for full PPIase activity and this amino acid was conserved in CbMip.

\section{Expression of cbmip by $E$. coli}

To examine whether the $c b m i p$ promoter was functional in $E$. coli, plasmids containing the cbmip gene in either orientation relative to the lac promoter of the vector were transcribed in vitro and translated (IVTT) using an E. coli extract. The IVTT data suggested that the cbmip gene had its own promoter within the 1.7 EcoRI-ClaI fragment because a protein was still produced with the cbmip gene in the opposite orientation to the lac promoter of pUC19 (pYMA1.6) (data not shown).

The $c b m i p$ gene was overexpressed in E.coli (pYMA1.14-1) 
(a)

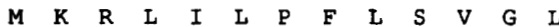
GAATCTCTAGCTTTCCTTGTIAAGATGGACGTCATTAACTCATAATTCAGGAGATCGCTGAATGAAACGATTGATTTTACCTTTCTTAAGTGTGGGCT 100 $-35$ $-10$

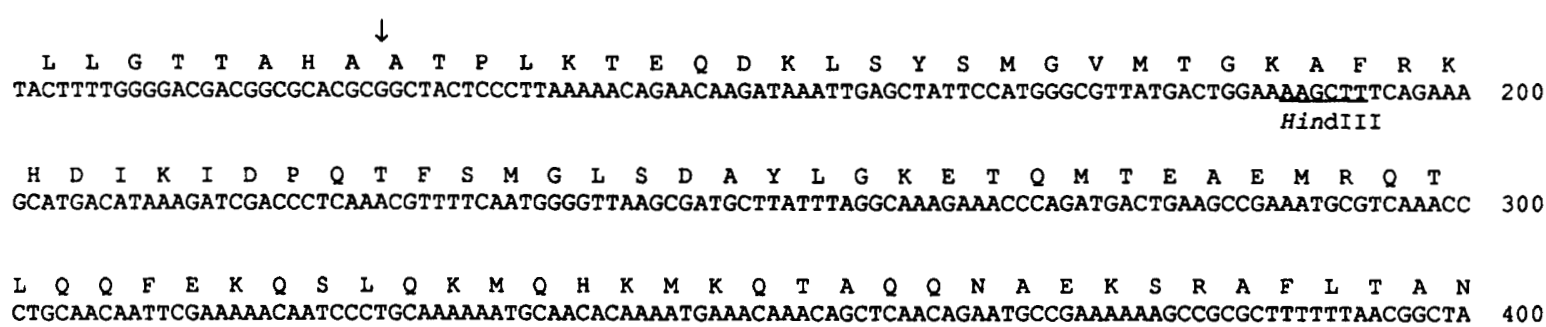

(b)

\begin{tabular}{|c|c|c|}
\hline LpMip & MKMKLVTAAVMGLAMSTAMAATDAT . . . . . . . SLATDKDKLSYSIGADLGKN & 45 \\
\hline & $\begin{array}{lllllll}11 & 1 & 1 & 1 & 1 & 11|1| 1 & 1\end{array}$ & \\
\hline CbMip & . . MKRLILPFLSVGLLLGTTAHAAT . . . . . . . . . . PLKTEQDKLSYSMGVMTGKA & 43 \\
\hline & 1111 & \\
\hline CtMip & . .MKN ILSWMLMF AVALP IVGCDNGGGSQTSATEKSMVEDSALTDNQKLSRTFGHLLARQ & 58 \\
\hline LpMip & F.KNQGIDVNPEAMAKGMQDAMSGAQLALTEQQMKDVLNKFQKDLMAKRTAEFNKKADEN & 104 \\
\hline & $1 \mid$ & \\
\hline CbMip & F . RKHDIKIGPQTFSMGLSDAYLGKE TQMTEAEMRQTLQQFEKQSLQKMQHKMKQTAQQN & 102 \\
\hline & 11 & \\
\hline CtMip & LSRTEDF SIDLVEVIKGMQSE IDGQSAPLTDTE . . . . . Y YEKQMAEVQKASFEAKCSEN & 111 \\
\hline & $\nabla$ & \\
\hline LpMip & KVKGEAF LTENKNKPGVVVL . P SGLQYKVINAGNGVKP GKSDTVTVEYTGRLIDGTVFDS & 163 \\
\hline & $1|1| 1|1| 1|11 \quad| \quad|1| 1 \mid 1 \quad 11111$ & \\
\hline CbMip & AEKSRAF LTANKNKPGVKTL . ANGLQYKVLQAGQGQSPTLNDEVTVNYEGRL INGTVFDS & 161 \\
\hline & $\begin{array}{lllllllllllllllll}11 & 11 & 1 & 11 & 1 & 1 & 1 & 1 & 1 & 1 & 1 & 1\end{array}$ & \\
\hline CtMip & LASAEEF LKENKEKAGVIELEPNKLQYRVVKEGTGRVLSGKPTALLHYTGSF IDGKVFDS & 171 \\
\hline LpMip & TEKTGKP ATFQVSQVIPGWTEALQLMP AGSTWEIYVPSGLAYGP RSVGGP IGPNETLIFK & 223 \\
\hline & 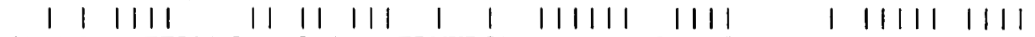 & \\
\hline CbMip & SYKRGNP ATFP LKSVIKGWQEALTRMKPGA IWEIYVPPQLAYGEQGAPGVIGPNEALIFK & 221 \\
\hline & $11 \quad 111$ & \\
\hline CtMip & SEKNKEP ILIPITKVIPGF SQGMQGMKEGEVRVLYIHPDLAYG . . . TAGQLPPNSLLIFE & 229 \\
\hline LpMip & $\begin{array}{l}\text { IHLISVKKSS } \ldots . . \\
\qquad|||| \mid\end{array}$ & \\
\hline CbMip & $\begin{array}{l}\text { VNLISVKKK } \ldots \ldots \\
|| \mid\end{array}$ & \\
\hline CtMip & VKLIEANDDNVSVTE & \\
\hline
\end{tabular}

Fig. 3. DNA sequence and deduced amino acid sequence of the cbmip gene (a) and sequence comparison (b). (a) The potential promoter region $(-10$ and -35$)$ is underlined and the potential RBS is bold. The dyad symmetry sequence at the $3^{\prime}$ end of the gene is indicated by opposite arrows. The arrow pointing down shows the putative leader sequence 


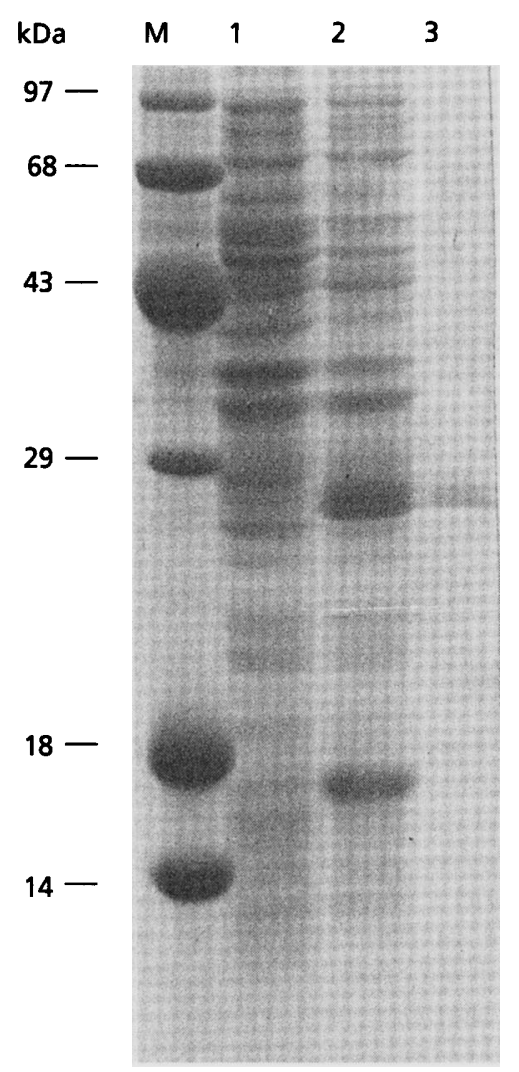

Fig. 4. Overexpression and purification of CbMip protein. Bacterial cultures were harvested $2 \mathrm{~h}$ after induction with $1 \mathrm{mM}$ IPTG. Proteins were resolved by SDS-PAGE (15\%) and stained with Coomassie Brilliant Blue. Lanes: $M$, protein markers with molecular mass indicated on the left in $\mathrm{kDa}$; 1 and 2 , whole cell lysates of $E$. coli harbouring PYMA1.14-2 and PYMA1.14-1, respectively; $3,1 \mu \mathrm{g}$ purified CbMip protein.

(Fig. 4). The expression was detected $1 \mathrm{~h}$ after induction and reached maximal levels at $3 \mathrm{~h}$ after induction. In contrast, when the cbmip gene in pYMA1.14-2 (same as pYMA1.14-1, but in opposite orientation) was overexpressed in E. coli, no band corresponding to CbMip was apparent. After separation by successive gel-filtration and ion-exchange chromatography, a protein band with a molecular mass of $24 \mathrm{kDa}$ was obtained (Fig. 4). Western blotting analysis using LpMip-specific antibodies confirmed that this protein was CbMip (Fig. 2, lane 5). The overproduced CbMip protein was soluble as it was purified from the supernatant fraction of cell extracts.

\section{PPlase activity of the recombinant CbMip}

The purified CbMip exhibited PPIase activity (Fig. 5a), comparable to that reported for other FKBPs (Sampson \& Gotchlich, 1992; Standaert et al., 1990). A consistently higher level of activity was observed using CbMip which
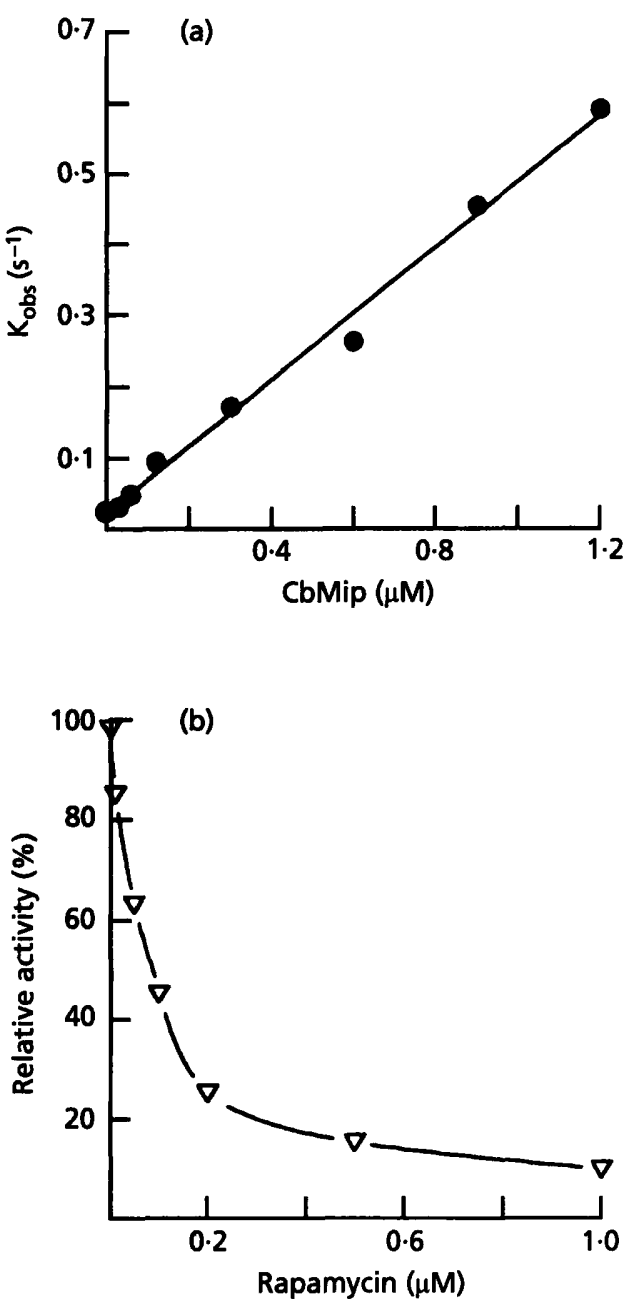

Fig. 5. PPlase activity of CbMip. (a) PPlase activity at various concentrations of CbMip. (b). Inhibition of PPlase activity of CbMip (100 nM) by rapamycin. The relative activity is calculated by comparing the enzymic activity in the absence or presence of rapamycin (Wyeth-Ayerst). One-hundred percent activity $\left(K_{\text {obs }}\right)$ of $100 \mathrm{nM}$ CbMip is $0.092 \mathrm{~s}^{-1}$. Data shown in the figure are from three experiments with SE $\leqslant 0.02$.

had been affinity-purified from all extracts containing pYMA1.35-1, providing additional evidence that the PPIase activity was due to CbMip (data not shown). Enzymic activity was inhibited by the immunosuppressive drug, rapamycin. Less than $20 \%$ relative activity, compared to that in the absence of rapamycin, remained when the drug concentration was $500 \mathrm{nM}$ (Fig. 5b).

\section{Processing of the CbMip precursor and possible export of CbMip in E. coli}

A potential $\mathrm{N}$-terminal signal peptide of CbMip was identified by computer analysis of the DNA-deduced amino acid sequence and the cleavage site predicted to be conserved in all three proteins and indicated by an open triangle. 


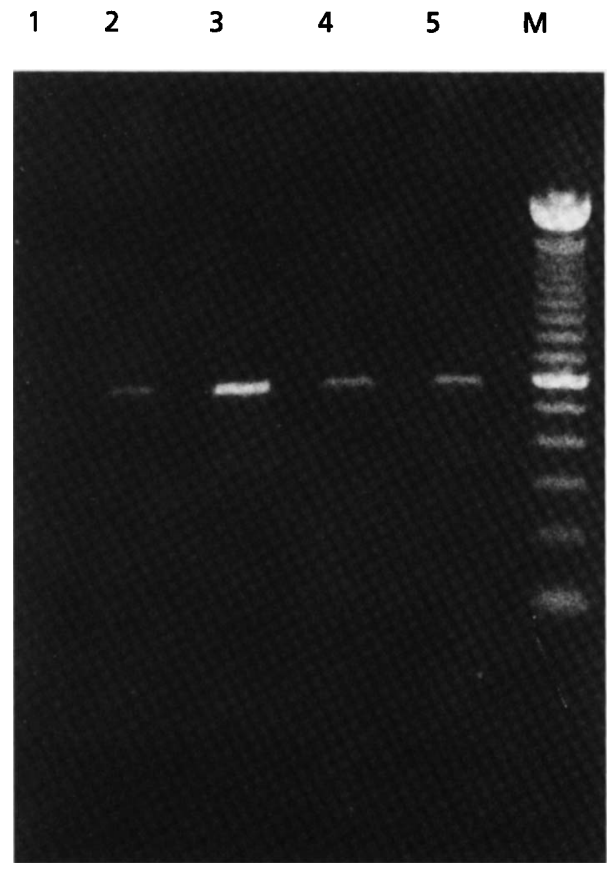

Fig. 6. PCR amplification of the cbmip fragment from DNA of various $C$. burnetii isolates. The amplified DNA products using primers $A 1-R 1$ and $A 1-U 1$ were separated in a $1.5 \%$ agarose gel. Lanes: 1, E. coli DNA; 2, Nine Mile phase I; 3, Priscilla; 4, K; 5, S; M, $100 \mathrm{bp}$ DNA ladder. Note a DNA band of $\sim 600 \mathrm{bp}$ from the different isolates of $C$. burnetii.

between amino acids Ala and Ala at positions 21 and 22 (Fig. 3a). N-terminal amino acid sequencing of CbMip confirmed this prediction. The first seven amino acids of CbMip purified from lysates of cells carrying pYMA1.14-1 was determined to be ATPLKTE. This corresponded to amino acids $22-28$ of CbMip (Fig. 3 a), demonstrating that the signal peptide was removed in $E$. coli. This explains why recombinant CbMip was not bound to the nickel-containing resin (Invitrogen) in attempts to purify this protein (data not shown). The mature protein has a molecular mass of $23.5 \mathrm{kDa}$.

The presence of a signal peptide at the $\mathrm{N}$ terminus of CbMip suggested secretion of the protein. Furthermore, the size of recombinant CbMip matched with that of LpMip (Fig. 1), suggesting that CbMip was processed to a mature protein. To further examine its possible surface expression in E. coli, the cbmip gene was subjected to Tnpho $A$ mutagenesis. Five inserts were identified by restriction mapping to be within the $c b m i p$ gene. pho $A$ was fused in-frame with the cbmip gene, as demonstrated by production of blue pigment on X-P plates. In one of the clones (pYMA1.201), pho $A$ was inserted between nucleotides 477 and 478 , as determined by nucleotide sequencing (Fig. 3a). In contrast, three randomly picked white colonies had insertions either in the opposite orientation to the cbmip gene, or fused to the cbmip gene but out-offrame (data not shown). Thus, the CbMip expressed in $E$. coli and detected by Western blotting was likely an exported, mature protein.

\section{Conservation of the cbmip gene}

To determine the extent of $c b m i p$ gene conservation in $C$. burnetii, primer pairs A1-R1 and A1-U1 specific to cbmip were used to PCR-amplify DNA from different isolates of C. burnetii. The results (Fig. 6) demonstrated the presence of an identical PCR product (582 bp), corresponding to nucleotides 182-764, in the Nine Mile phase I, Priscilla, K and $\mathrm{S}$ isolates representing various disease-causing agents and genetic backgrounds (Samuel et al., 1985). An identical band was detected in the Nine Mile phase II isolate (data not shown). Although the Nine Mile phase II isolate is avirulent in animals, it does infect and grow in the phagolysosomes of cultured cells (Baca \& Paretsky, 1983).

\section{DISCUSSION}

In this study a mip analogue was cloned from $C$. burnetii and its nucleotide sequence determined. The predicted amino acid sequence of the gene product was shown to have a high degree of identity and similarity to those of $L$. pneumophila and Chl. trachomatis Mip/Mip-like proteins. Mip/Mip-like proteins belong to the prokaryotic and eukaryotic FKBP family based on their amino acid sequence similarities and PPIase activity (Hacker \& Fischer, 1993). The prokaryotic FKBPs appear to fall into two categories. The larger $(\geqslant 24 \mathrm{kDa})$ FKBPs or Mip/ Mip-like proteins of L. pneumophila and Chl. trachomatis are membrane-associated and/or secreted, while those present in bacteria generally not considered to be intracellular pathogens are smaller $(\leqslant 12 \mathrm{kDa})$ and appear to be cytosolic proteins (Sampson \& Gotchlich, 1992). A possible exception to this general finding is a report that $E$. coli encodes a $28849 \mathrm{Da}$ FKBP-like protein with 28-34\% identity to known Mip-like proteins (Horne \& Young, 1994). By PCR amplification we also demonstrated that the cbmip gene was present in all $C$. burnetii isolates tested, including isolates from cases of acute and chronic Q fever. Mip/Mip-like proteins have been shown to be important for L. pneumophila and Chl. trachomatis infections (Cianciotto et al., 1990 b, 1995a; Cianciotto \& Fields, 1992; Lundemose et al., 1992). With its high sequence similarity and similar enzyme activity to Mip/ Mip-like proteins, CbMip may be a $C$. burnetii virulence factor.

Mip/Mip-like proteins $(\geqslant 24 \mathrm{kDa}$ ) have been identified in at least three intracellular bacterial pathogens, i.e. $L$. pneumopbila, Cbl. trachomatis and C. burnetii. Whether these organisms adopt a similar mechanism of resistance to host killing is not clear, but following entry into the host cell, they grow in different cellular compartments (Weiss et al., 1991). For instance, both L. pneumophila and Cbl. trachomatis reside in a phagosome, while acidification of the phagosome by lysosomal fusion is a necessary event that initiates active metabolism and proliferation of $C$. burnetii (Hackstadt \& Williams, 1981). In contrast, these organisms have developed similar strategies for the early steps of infection, in which Mip proteins may play a central role. Indeed, LpMip and CtMip have both been 
shown to affect some earlier stage of host-parasite interaction of L. pneumophila and Chl. trachomatis. Unfortunately, the early steps of $C$. burnetii host interaction are not clear due to a lack of information on cell-surface recognition, attachment and entry processes. For example, it is still not known whether $C$. burnetii is passively phagocytosed into host cells or whether factors from the pathogen are involved (Baca \& Paretsky, 1983; Williams et al., 1989).

Because of its exposure to the cell surface, LpMip was shown to be involved in interaction with host cells (Engleberg et al., 1989). CbMip appears to be processed to a mature protein by cleavage of the signal peptide, as demonstrated by $\mathrm{N}$-terminal amino acid sequencing. Moreover, $\operatorname{Tn} p h o A$ mutagenesis suggests that CbMip is an exported protein in $E$. coli. Whether CbMip is actually secreted by $C$. burnetii is currently being investigated. Of interest is the recent observation that viable $C$. burnetii cells incubated in host-cell-free medium at low $\mathrm{pH}$ rapidly synthesize and export several proteins, one of which is similar in molecular mass to CbMip (Redd \& Thompson, 1995). The synthesis and secretion of proteins by $C$. burnetii subjected to low $\mathrm{pH}$ (in vitro) suggests that this might occur as the organism is being taken in by endocytosis. If CbMip is secreted, one could speculate that it would interact with host components both during uptake and intracellular growth. Identification of CbMip would appear to support the argument that infection of host cells by $C$. burnetii is an active process, in that it requires the presence of specific virulence components.

While the significance of the observation is not known, it is worth noting that CbMip, like LpMip, is a very basic protein. Predicted pIs for LpMip and CbMip are $9 \cdot 8$ (Engleberg et al., 1989) and 10.7, respectively. It will be interesting to see if the basic nature of these secreted proteins is related to a common feature of their different intracellular niches.

Although Mip/Mip-like proteins have been studied in great detail (Hacker \& Fischer, 1993), how they function during host-parasite interaction is still unknown. The recent finding of significant homology to FKBPs may provide some clues as to the physiological function of Mip-related proteins. FKBPs exhibit PPIase activity which may mediate folding of proteins (Fischer \& Schmid, 1990; Tropschug et al., 1990). The enzymic activity of both Mip-related proteins and FKBPs is inhibited by binding to FK506 or rapamycin (Fretz et al., 1991), but the direct target for FK506 has been shown to be calcineurin (Fruman et al., 1992; O'Keefe et al., 1992), a calcium- and calmodulin-dependent phosphatase that is required for the activation of the cytoplasmic nuclear factor of activated $T$ cells. It will be interesting to see whether impairing host FKBP function leads to facilitated uptake by host macrophages or the intracellular survival of the parasite. Given the potential secretory feature of Mip/Mip-like proteins, one cannot exclude the possibility that such proteins are able to bind to the natural ligand of host FKBPs, thus deregulating the host immune system.

\section{ACKNOWLEDGEMENTS}

The software cited is part of the VADMS ${ }^{\circledR}$ Center, a campuswide computer resource at Washington State University. This work was supported by grant AI20190 from the National Institutes of Health (NIAID).

\section{REFERENCES}

Ausubel, F. M., Brent, R., Kingston, R. E., Moore, D. D., Seidman, J. G., Smith, J. A. \& Struhl, K. (1989). Current Protocols in Molecular Biology. New York: Wiley-Interscience.

Baca, O. G. \& Paretsky, D. (1983). Q-fever and Coxiella burnetii: a model for host-parasite interactions. Microbiol Rev 47, 127-149.

Baca, O. G., Roman, M. J., Glew, R. H., Christner, R. F., Buhler, J. E. \& Aragon, A. S. (1993). Acid phosphatase activity in Coxiella burnetii: a possible virulence factor. Infect Immun 61, 4232-4239.

Bangsborg, J. M., Cianciotto, N. P. \& Hindersson, P. (1991). Nucleotide sequence analysis of the Legionella midadei mip gene, encoding a 30-kilodalton analog of the Legionella pneumopbila Mip protein. Infect Immun 59, 3836-3840.

Bullock, W. O., Fernandez, J. M. \& Short, J. M. (1987). XL1-blue: a high efficiency plasmid transforming $\operatorname{rec} A$ Escherichia coli strain with $\beta$-galactosidase selection. BioTecbniques 4, 376-379.

Cianciotto, N. P. \& Fields, B. S. (1992). Legionella pneumophila mip gene potentiates intracellular infection of protozoa and human macrophages. Proc Natl Acad Sci US A 89, 5188-5191.

Cianciotto, N. P., Eisenstein, B. I., Mody, C. H., Toews, G. B. \& Engleberg, N. C. (1989). A Legionella pneumophila gene encoding a species-specific surface protein potentiates initiation of intracellular infection. Infect Immun 57, 1255-1262.

Cianciotto, N. P., Bangsborg, J. M., Eisenstein, B. I. \& Engleberg, N. C. (1990a). Identification of mip-like genes in the genus Legionella. Infect Immun 58, 2912-2918.

Cianciotto, N. P., Eisenstein, B. I., Mody, C. H. \& Engleberg, N. C. (1990b). A mutation in the mip gene results in an attenuation of Legionella pneumophila virulence. J Infect Dis 162, 121-126.

Cianciotto, N. P., Kim-Stamos, J. K. \& Kamp, D. W. (1995a). Infectivity of a Legionella pneumopbila mip mutant for alveolar epithelial cells. Curr Microbiol 30, 247-250.

Cianciotto, N. P., O'Connell, W., Dasch, G. A. \& Mallavia, L. P. (1995b). Detection of mip-like sequences and Mip-related proteins within the family Rickettsiaceae. Curr Microbiol 30, 149-153.

Devereux, J., Haeberli, P. \& Smithies, O. (1984). A comprehensive set of sequence analysis programs for the VAX. Nucleic Acids Res 12, 387-395.

Engleberg, N. C., Carter, C., Weber, D. R., Cianciotto, N. P. \& Eisenstein, B. I. (1989). DNA sequence of mip, a Legionella pneumophila gene associated with macrophage infectivity. Infect Immun 57, 1263-1270.

Etzkorn, F. A., Stoley, L. A., Chang, Z. \& Walsh, C. T. (1993). Role of the cyclosporin A-cyclophilin complex, FK506-binding protein complex and calcineurin in the inhibition of T-cell signal transduction. Curr Opin Struct Biol 3, 929-933.

Fischer, G. \& Schmid, F. X. (1990). The mechanism of protein folding. Implications of in vitro refolding models for de novo protein folding and translocation in the cell. Biocbemistry 29, 2205-2212.

Fischer, G., Bang, H., Ludwig, B., Mann, K. \& Hacker, J. (1992). Mip protein of Legionella pneumophila exhibits peptidyl-prolylcis/trans isomerase (PPIase) activity. Mol Microbiol 6, 1375-1383. 
Fretz, H. M., Albers, W., Galat, A., Standaert, R. F., Lane, W. S., Burakoff, S. J., Bierer, B. E. \& Schreiber, S. L. (1991). Rapamycin and FK506 binding proteins (immunophilins). J Am Chem Soc 113, 1409-1411.

Fruman, D. A., Klee, C. B., Bierer, B. E. \& Burakoff, S. J. (1992). Calcineurin phosphatase activity in $\mathrm{T}$ lymphocytes is inhibited by FK506 and cyclosporin A. Proc Natl Acad Sci US A 89, 3686-3690.

Hacker, J. \& Fischer, G. (1993). Immunophilins: structure-function relationship and possible role in microbial pathogenicity. Mol Microbiol 10, 445-456.

Hackstadt, T. \& Williams, J. C. (1981). Biochemical stratagem for obligate parasitism of eukaryotic cells by Coxiella burnetii. Proc Natl Acad Sci US A 78, 3240-3244.

Harrison, R. K. \& Stein, R. L. (1990). Substrate specificities of the peptidyl-prolyl cis-trans isomerase activities of cyclophilin and FK506 binding protein: evidence for the existence of a family of distinct enzymes. Biocbemistry 29, 3813-3816.

Hawley, D. K. \& McClure, W. R. (1983). Compilation and analysis of Escherichia coli promoter DNA sequences. Nucleic Acids Res 11, 2237-2255.

Heinzen, R. A. \& Mallavia, L. P. (1987). Cloning and functional expression of the Coxiella burnetii citrate synthase gene in Escherichia coli. Infect Immun 55, 848-855.

Heinzen, R. A., Frazier, M. E. \& Mallavia, L. P. (1992). Coxiella burnetii superoxide dismutase gene: cloning, sequencing, and expression in Escherichia coli. Infect Immun 60, 3814-3823.

Hendrix, L. R. \& Mallavia, L. P. (1984). Active transport of proline by Coxiella burnetii. J Gen Microbiol 130, 2857-2863.

Hendrix, L. R., Mallavia, L. P. \& Samuel, J. E. (1993). Cloning and sequencing of Coxiella burnetii outer membrane protein gene com1. Infect Immun 61, 470-477.

Hoover, T. A. \& Vodkin, M. H. (1991). Cloning and expression of Coxiella burnetii DNA. In Q Fever: The Biology of Coxiella burnetii, pp. 285-310. Edited by J. C. Williams \& H. A. Thompson. Boca Raton, FL: CRC Press.

Hoover, T. A., Vodkin, M. H. \& Williams, J. C. (1992). A Coxiella burnetii repeated DNA element resembling a bacterial insertion sequence. $J$ Bacteriol 174, 5540-5548.

Horne, S. M. \& Young, K. D. (1994). Characterization of an E. coli gene that encodes a new member of the family of FK506 binding proteins. Abstr Annu Meet Am Soc Microbiol B-359, 93.

Kofron, J. L., Kuzmic, P., Kishore, V., Colon-Bonilla, E. \& Rich, D. H. (1991). Determination of kinetic constants for peptidyl prolyl cistrans isomerases by an improved spectrophotometric assay. Biochemistry 30, 6127-6134.

Kyte, J. \& Doolittle, R. F. (1982). A simple method for displaying the hydropathic character of a protein. J Mol Biol 157, 105-132.

Laemmli, U. K. (1970). Cleavage of structural proteins during the assembly of the head of bacteriophage T4. Nature 227, 680-685.

Ludwig, B., Rahfeld, J., Schmidt, B., Mann, K., Wintermeyer, E., Fischer, G. \& Hacker, J. (1994). Characterization of Mip proteins of Legionella pneumophila. FEMS Microbiol Lett 118, 23-30.

Lundemose, A. G., Rouch, D. A., Birkelund, S., Christiansen, G. \& Pearce, J. H. (1992). Chlamydia trachomatis Mip-like protein. Mol Microbiol 6, 2539-2548.

Lundemose, A. G., Kay, J. E. \& Pearce, J. H. (1993). Chlamydia trachomatis Mip-like protein has peptidyl-prolyl cis/trans isomerase activity that is inhibited by FK506 and rapamycin and is implicated in initiation of chlamydial infection. Mol Microbiol 7, 777-783.
Mallavia, L. P. (1991). Genetics of Rickettsiae. Eur J Epidemiol 7, 213-221.

Manoil, C. \& Beckwith, J. (1985). Tnpho $A$ : a transposon probe for protein export signals. Proc Natl Acad Sci US A 82, 8129-8133.

Mo, Y. \& Mallavia, L. P. (1994). A Coxiella burnetii gene encodes a sensor-like protein. Gene 151, 185-190.

Moulder, J.W. (1985). Comparative biology of intracellular parasitism. Microbiol Rev 49, 298-337.

Mozier, N. M., Zurcher-Neely, H. A., Guido, D. M., Mathew, W. R., Heinrikson, R. L., Fraser, E. D., Walsh, M. P. \& Pearson, J. D. (1990). Amino acid sequence of a $12-\mathrm{kDa}$ inhibitor of protein kinase C. Eur J Biochem 194, 19-23.

Nelson, P. A., Lippke, J. A., Murcko, M. A., Rosborough, S. L. \& Peattie, D. A. (1991). cDNA encoding murine FK506-binding protein (FKBP): nucleotide and deduced amino acid sequences. Gene 109, 255-258.

Neuhoff, V., Stamm, R. \& Eibl, H. (1985). Clear background and highly sensitive protein staining with Coomassie Blue dyes in polyacrylamide gels: a systematic analysis. Electrophoresis 6, 427-448.

O'Keefe, S. J., Tamura, J., Kincaid, R. L., Tocci, M. J. \& O'Neill, E. A. (1992). FK-506 and CsA-sensitive activation of the interleukin2 promoter by calcineurin. Nature 357, 692-694.

Pahl, A. \& Keller, U. (1992). FK-506 binding proteins from Streptomycetes producing immunosuppressive macrolactones of the FK-506 type. $J$ Bacteriol 174, 5888-5894.

Redd, T. \& Thompson, H. A. (1995). Secretion of proteins by Coxiella burnetii. Microbiol 141, 363-369.

Reiland, J. (1970). Gel filtration. Methods Enzymol 22, 287-412.

Russel, M., Kidd, S. \& Kelley, M. R. (1986). An improved filamentous helper phage for generating single-stranded plasmid DNA. Gene 45, 333-338.

Sampson, B. A. \& Gotchlich, E. C. (1992). Neisseria meningitidis encodes an FK506-inhibitable rotamase. Proc Natl Acad Sci US A 89, 1164-1168.

Samuel, J. E., Frazier, M. E. \& Mallavia, L. P. (1985). Correlation of plasmid type and disease caused by Coxiella burnetii. Infect Immun 49, 775-779.

Sanger, F., Nicklen, S. \& Coulson, A. R. (1977). DNA sequencing with chain-terminating inhibitors. Proc Natl Acad Sci USA 74, 5463-5467.

Shine, J. \& Dalgarno, L. (1975). Determinant of cistron specificity in bacterial ribosomes. Nature 254, 34-38.

Standaert, R. F., Galat, A., Verdine, G. L. \& Schreiber, S. L. (1990). Molecular cloning and overexpression of the human FK506binding protein FKBP. Nature 346, 671-674.

Tropschug, M., Wachter, E., Mayer, S., Schonbrunner, S. R. \& Schmid, F. X. (1990). Isolation and sequence of an FK506-binding protein from $N$. crassa which catalyses protein folding. Nature 346, 674-677.

Vodkin, M. H. \& Williams, J. C. (1988). A heat shock operon in Coxiella burnetii produces a major antigen homologous to a protein in both mycobacteria and Escherichia coli. J Bacteriol 170, 1227-1234.

Weisburg, W. G., Dobson, M. E., Samuel, J. E., Dasch, G. A., Mallavia, L. P., Baca, O., Mandelco, L., Sechrest, J. E., Weiss, E. \& Woese, C. R. (1989). Phylogenetic diversity of the rickettsiae. $J$ Bacteriol 171, 4202-4206.

Weiss, E., Williams, J. C. \& Thompson, H. A. (1991). The place of Coxiella burnetii in the microbial world. In $Q$ Fever: The Biology of 
Coxiella burnetii, pp. 1-19. Edited by J. C. Williams \& H. A. Thompson. CRC Press, Boca Raton, Florida.

Williams, J. C., McCaul, T. F., Thompson, H. A. \& Waag, D. M.

(1989). Molecular strategies for uptake and phagolysosomal growth of Coxiella burnetii in nonimmune and immune hosts. In Intracellular Parasitism, pp. 127-140. Edited by J. W. Moulder. Boca Raton, FL: CRC Press.
Yanisch-Perron, C., Vieira, J. \& Messing, J. (1985). Improved M13 cloning vectors and host strains: nucleotide sequences of the M13 mp18 and pUC19 vectors. Gene 33, 103-119.

Received 14 March 1995; revised 26 June 1995; accepted 10 July 1995. 